\title{
Para descolonizar os estudos de economia política e os estudos pós-coloniais: Transmodernidade, pensamento de fronteira $\mathrm{e}$ colonialidade global
}

\author{
Ramón Grosfoguel
}

Discutem-se as implicações epistemológicas da viragem descolonial para a descolo-nização do conceito de "capitalismo global", tal como tem sido usado nos paradigmas da economia política e dos estudos culturais. Entre outros termos discutidos no artigo, incluem-se "colonização do poder", "epistemologias de fronteira" e "transmodernidade", para começar a pensar, não de acordo com "novas utopias", mas antes com "outras utopias" baseadas numa cartografia diferente das relações de poder globais no âmbito do "sistema mundo europeu/euro-norte-americano moderno/capitalista colonial/patriarcal". O artigo defende a necessidade de usar este último conceito (apesar da sua extensão) e de abandonar a categoria de "sistema-mundo capitalista" ou "capitalismo global".

Tradução de Inês Martins Ferreira

Será que podemos criar uma política anticapitalista radical que vá além da política identitária? Será possível formular um cosmopolitismo crítico que vá além do nacionalismo e do colonialismo? Será que podemos criar conhecimentos que vão além dos fundamentalismos terceiro-mundistas e eurocêntricos? Será que podemos superar a tradicional dicotomia entre economia política e estudos culturais? Será que podemos transpor o reducionismo económico e o culturalismo? Como podemos nós ultrapassar a modernidade eurocêntrica sem desperdiçar o melhor da modernidade, como fizeram muitos fundamentalistas do Terceiro Mundo? Neste artigo, proponho que uma perspectiva epistémica proveniente do lado subalterno da diferença colonial trará um grande contributo a este debate. Pode contribuir para a criação de uma perspectiva crítica capaz de 
transcender as dicotomias delineadas e para a redefinição do capitalismo enquanto sistema-mundo.

Em Outubro de 1998, teve lugar na Universidade de Duke um congresso/diálogo entre o Grupo Sul-asiático de Estudos Subalternos e o Grupo Latino-americano de Estudos Subalternos. O diálogo iniciado neste congresso viria a dar origem à publicação de vários números da revista científica Nepantla. Contudo, foi essa a última vez que o Grupo Latino-americano de Estudos Subalternos se reuniu, antes de se desagregar. Entre os muitos motivos e debates que causaram essa desagregação, existem dois que gostaria de salientar. Os membros do Grupo Latino-americano de Estudos Subalternos eram, na maioria, académicos latinoamericanistas a viver nos EUA. Apesar de terem tentado produzir um conhecimento alternativo e radical, eles reproduziram o esquema epistémico dos Estudos Regionais nos Estados Unidos. Salvo raras excepções, optaram por fazer estudos sobre a perspectiva subalterna, em vez de os produzir com essa perspectiva e a partir dela. À semelhança da imperial epistemologia dos Estudos Regionais, a teoria permaneceu sediada no Norte, enquanto os sujeitos a estudar se encontram no Sul. Esta epistemologia colonial foi determinante para o meu descontentamento com o projecto. Sendo eu um latino a viver nos Estados Unidos, fiquei descontente com as consequências epistémicas do conhecimento produzido por esse grupo latino-americanista. Os seus membros subestimaram, na sua obra, as perspectivas étnico-raciais oriundas da região, dando preferência sobretudo a pensadores ocidentais. Isto está relacionado com o segundo aspecto que queria salientar: os latino-americanistas deram preferência epistemológica ao que chamaram "os quatro cavaleiros do Apocalipse” (Mallon, 1994; Rodriguez, 2001), ou seja, a Foucault, Derrida, Gramscie Guha. Entre estes quatro, contamse três pensadores eurocêntricos, fazendo dois deles (Derrida e Foucault) parte do cânone pós-estruturalista/pós-moderno ocidental. Apenas um, Rinajit Guha, é um pensador que pensa a partir do Sul. Ao preferirem pensadores ocidentais como principal instrumento teórico, traíram o seu objectivo de produzir estudos subalternos. 
Entre as muitas razões que conduziram à desagregação do Grupo Latinoamericano de Estudos Subalternos, uma delas foi a que veio opor os que consideravam a subalternidade uma crítica pós-moderna (o que representa uma crítica eurocêntrica ao eurocentrismo) àqueles que a viam como uma crítica descolonial (o que representa uma crítica do eurocentrismo por parte dos saberes silenciados e subalternizados) (Mignolo, 2000: 183-186, 213-214). Para todos nós que tomámos o partido da crítica descolonial, o diálogo com o Grupo Latinoamericano de Estudos Subalternos tornou evidente a necessidade de transcender epistemologicamente - ou seja, de descolonizar - a epistemologia e o cânone ocidentais. O principal projecto do Grupo Sul-asiático de Estudos Subalternos consiste em analisar criticamente não só a historiografia colonial da Índia feita por ocidentais europeus, mas também a historiografia eurocêntrica nacionalista indiana. Porém, ao recorrer a uma epistemologia ocidental e ao privilegiar Gramsci e Foucault, tal perspectiva constrangeu e limitou a radicalidade da sua crítica ao euro-centrismo. Embora estes autores representem diferentes projectos epistémicos, o privilegiar do cânone epistémico ocidental por parte da escola subalterna sul-asiática acabou por espelhar o apoio dado ao pós-modernismo pelo sector do Grupo Latino-americano de Estudos Subalternos. Não obstante, ainda que com todas as suas limitações, o Grupo Sul-asiático de Estudos Subalternos representa um importante contributo para a crítica do eurocentrismo. O grupo insere-se num movimento intelectual denominado crítica pós-colonial (uma crítica da modernidade vinda do Sul Global) por oposição à crítica pós-moderna do Grupo Latino-americano de Estudos Subalternos (uma crítica da modernidade feita pelo Norte Global) (Mignolo, 2000). Estes debates tornaram claro para nós (aqueles que tomaram o partido da crítica descolonial acima descrita) que era necessário descolonizar não apenas os Estudos Subalternos mas também os Estudos Pós-coloniais (Grosfoguel 2006a, 2006b).

Esta não é uma crítica anti-europeia fundamentalista e essencialista. Trata-se de uma perspectiva que é crítica em relação ao nacionalismo, ao colonialismo e aos fundamentalismos, quer eurocêntricos, quer do Terceiro Mundo. O pensamento 
de fronteira, uma das perspectivas epistémicas que serão discutidas neste artigo, é, precisamente, uma resposta crítica aos fundamentalismos, sejam eles hegemónicos ou marginais. O que todos os fundamentalismos têm em comum (incluindo o eurocêntrico) é a premissa de que existe apenas uma única tradição epistémica a partir da qual pode alcançar-se a Verdade e a Universalidade. No entanto, há três aspectos importantes que têm de ser aqui referidos: 1) uma perspectiva epistémica descolonial exige um cânone de pensamento mais amplo do que o cânone ocidental (incluindo o cânone ocidental de esquerda); 2) uma perspectiva descolonial verdadeiramente universal não pode basear-se num universal abstracto (um particular que ascende a desenho - ou desígnio universal global), antes teria de ser o resultado de um diálogo crítico entre diversos projectos críticos políticos/éticos/epistémicos, apontados a um mundo pluriversal e não a um mundo universal; 3) a descolonização do conhecimento exigiria levar a sério a perspectiva/cosmologias/visões de pensadores críticos do Sul Global, que pensam com e a partir de corpos e lugares étnico-raciais/sexuais subalternizados. Enquanto projectos epistemológicos, o pós-modernismo e o pósestruturalismo encontram־se aprisionados no interior do cânone ocidental, reproduzindo, dentro dos seus domínios de pensamento e prática, uma determinada forma de colonialidade do poder/conhecimento.

No entanto, o que disse acerca do Grupo Latino-americano de Estudos Subalternos aplica-se aos paradigmas da economia política. Neste artigo, proponho que uma perspectiva epistémica que parta de lugares étnico-raciais subalternos pode contribuir em muito para uma teoria crítica descolonial radical, capaz de transcender a forma como os paradigmas da economia política tradicional conceptualizam o capitalismo enquanto sistema global ou sistemamundo. A ideia aqui é descolonizar os paradigmas da economia política, bem como a análise do sistema-mundo, e propor uma conceptualização descolonial alternativa do sistema-mundo. A primeira parte consiste numa discussão epistémica sobre as implicações da crítica epistemológica que intelectuais feministas e de grupos étnico-raciais subalternizados dirigiram contra a 
epistemologia ocidental. A segunda parte apresenta as implicações destas críticas no modo como conceptualizamos o sistema-mundo ou global. A terceira parte é uma discussão da colonialidade global dos nossos dias. A quarta parte é uma crítica, quer à análise do sistema-mundo, quer aos estudos pós-coloniais/culturais que usam a colonialidade do poder como resposta ao dilema cultura versus economia. Por fim, a quinta, sexta, sétima e última partes são uma discussão do pensamento de fronteira, da transmodernidade e da socialização do poder como alternativas descoloniais ao actual sistema-mundo.

\section{A crítica epistemológica}

O primeiro aspecto a discutir é o contributo das perspectivas subalternas étnicoraciais e feministas para as questões epistemológicas. Os paradigmas eurocêntricos hegemónicos que ao longo dos últimos quinhentos anos inspiraram a filosofia e as ciências ocidentais do "sistema-mundo patriarcal/capitalista/colonial/moderno" (Grosfoguel, 2005, 2006b) assumem um ponto de vista universalista, neutro e objectivo. Algumas intelectuais feministas chicanas e negras (Moraga e Anzaldúa, 1983; Collins, 1990) e também alguns estudiosos do Terceiro Mundo, tanto dentro como fora dos Estados Unidos (Dussel, 1977; Mignolo, 2000), vieram recordar-nos que falamos sempre a partir de um determinado lugar situado nas estruturas de poder. Ninguém escapa às hierarquias de classe, sexuais, de género, espirituais, linguísticas, geográficas e raciais do "sistema-mundo patriarcal/capitalista/colonial/moderno". Como afirma a feminista Donna Haraway (1988), os nossos conhecimentos são, sempre, situados. As estudiosas feministas negras apelidaram esta perspectiva de “epistemologia afrocêntrica" (Collins, 1990) (o que não é o mesmo que perspectiva afrocentrista). Já Enrique Dussel, filósofo da libertação latino-americano, denominou-a "geopolítica do conhecimento" (Dussel, 1977), e eu, na esteira de Fanon (1967) e Anzaldúa (1987), irei usar a expressão "corpo-política do conhecimento". 
Esta questão não tem a ver apenas com valores sociais na produção de conhecimento nem com o facto de o nosso conhecimento ser sempre parcial. O essencial aqui é o locus da enunciação, ou seja, o lugar geopolítico e corpo-político do sujeito que fala. Na filosofia e nas ciências ocidentais, aquele que fala está sempre escondido, oculto, apagado da análise. A "ego-política do conhecimento" da filosofia ocidental sempre privilegiou o mito de um "Ego" não situado. O lugar epistémico étnico-racial/sexual/de género e o sujeito enunciador encontram-se, sempre, desvinculados. Ao quebrar a ligação entre o sujeito da enunciação e o lugar epistémico étnico-racial/sexual/de género, a filosofia e as ciências ocidentais conseguem gerar um mito sobre um conhecimento universal Verdadeiro que encobre, isto é, que oculta não só aquele que fala como também o lugar epistémico geo-olítico e corpo-político das estruturas de poder/conhecimento colonial, a partir do qual o sujeito se pronuncia.

Eis que se torna importante distinguir "lugar epistémico" e "lugar social". O facto de alguém se situar socialmente no lado oprimido das relações de poder não significa automaticamente que pense epistemicamente a partir de um lugar epistémico subalterno. Justamente, o êxito do sistema-mundo colonial/moderno reside em levar os sujeitos socialmente situados no lado oprimido da diferença colonial a pensar epistemicamente como aqueles que se encontram em posições dominantes. As perspectivas epistémicas subalternas são uma forma de conhecimento que, vindo de baixo, origina uma perspectiva crítica do conhecimento hegemónico nas relações de poder envolvidas. Não estou a reivindicar um populismo epistémico em que o conhecimento produzido a partir de baixo seja automaticamente um conhecimento epistémico subalterno. $\mathrm{O}$ que defendo é o seguinte: todo o conhecimento se situa, epistemicamente, ou no lado dominante, ou no lado subalterno das relações de poder, e isto tem a ver com a geopolítica e a corpo-política do conhecimento. A neutralidade e a objectividade desinserida e não-situada da egopolítica do conhecimento é ummito ocidental. 
René Descartes, fundador da filosofia ocidental moderna, inaugura um novo momento na história do pensamento do Ocidente. Descartes substitui Deus, fundamento do conhecimento na teopolítica do conhecimento da Europa da Idade Média, pelo Homem (ocidental), fundamento do conhecimento na Europa dos tempos modernos. Todos os atributos de Deus são agora extrapolados para o Homem (ocidental). Essa Verdade universal que está para além do tempo e do espaço, o acesso privilegiado às leis do universo, e a capacidade de produzir conhecimento e teorias científicas, tudo isto está agora situado na mente do Homem ocidental. O ego-cogito cartesiano ("Penso, logo existo") é o fundamento das ciências modernas ocidentais. Ao criar um dualismo entre mente e corpo e entre mente e natureza, Descartes conseguiu proclamar um conhecimento nãosituado, universal, visto pelos olhos de Deus. A isto o filósofo colombiano Santiago Castro-Gomez chamou a perspectiva do "ponto zero" das filosofias eurocêntricas (Castro-Gomez, 2003). O "ponto zero" é o ponto de vista que se esconde e, escondendo-se, se coloca para lá de qualquer ponto de vista, ou seja, é o ponto de vista que se representa como não tendo um ponto de vista. É esta visão através do olhar de deus que esconde sempre a sua perspectiva local e concreta sob um universalismo abstracto. A filosofia ocidental privilegia a "egopolítica do conhecimento" em desfavor da "geopolítica do conhecimento" e da "corpo-política do conhecimento". Em termos históricos, isto permitiu ao homem ocidental (esta referência ao sexo masculino é usada intencionalmente) representar o seu conhecimento como o único capaz de alcançar uma consciência universal, bem como dispensar o conhecimento não-ocidental por ser particularístico e, portanto, incapaz de alcançar a universalidade.

Esta estratégia epistémica tem sido crucial para os desenhos - ou desígnios globais do Ocidente. Ao esconder o lugar do sujeito da enunciação, a dominação e a expansão coloniais europeias/euro-americanas conseguiram construir por todo o globo uma hierarquia de conhecimento superior e inferior e, consequentemente, de povos superiores e inferiores. Passámos da caracterização de "povos sem escrita" do século XVI, para a dos "povos sem história" dos séculos XVIII e XIX, 
"povos sem desenvolvimento" do século XX e, mais recentemente, "povos sem democracia" do século XXI. Passámos dos "direitos dos povos" do século XVI (o debate Sepúlveda versus de las Casas na escola de Salamanca em meados do século XVI), para os "direitos do homem" do século XVIII (filósofos iluministas), para os recentes "direitos humanos" do século XX. Todos estes fazem parte de desenhos globais, articulados simultaneamente com a produção e a reprodução de uma divisão internacional do trabalho feita segundo um centro e uma periferia, que por sua vez coincide com a hierarquia étnico-racial global estabelecida entre europeus e não-europeus.

Porém, como nos relembrou Enrique Dussel (1994), o ego cogito cartesiano ("Penso, logo existo") foi precedido, 150 anos antes (desde o início da expansão colonial europeia em 1492), pelo europeu ego conquistus ("Conquisto, logo existo"). As condições históricas, políticas, económicas e sociais que possibilitaram a um sujeito assumir a arrogância de se assemelhar a Deus e de se arvorar em fundamento de todo o conhecimento Verídico foi o Ser Imperial, ou seja, a subjectividade daqueles que estão no centro do mundo porque já o conquistaram. Quais as implicações descoloniais desta crítica epistemológica na nossa produção de conhecimento e no nosso conceito de sistema-mundo?

\section{A colonialidade do poder enquanto matriz de poder no mundo colonial/moderno}

Salvo raras excepções, os estudos dedicados à globalização, os paradigmas da economia política e a análise do sistema-mundo não tiraram as ilações epistemológicas e teóricas da crítica epistémica proveniente dos lugares subalternos cavados pelo fosso colonial, que encontraram expressão no meio académico através dos estudos étnicos e dos estudos feministas. Com efeito, essas abordagens continuam a produzir conhecimento através dos olhos de deus, a partir do "ponto zero" do homem ocidental. Isto gerou importantes problemas no que respeita à forma como conceptualizamos o capitalismo global e o "sistemamundo". Estes conceitos precisam de ser descolonizados e tal só pode ser 
conseguido por meio de uma epistemologia descolonial que assuma abertamente uma geopolítica e uma corpo-política do conhecimento descoloniais como pontos de partida para uma crítica radical. Os exemplos que se seguem podem ilustrar esta questão.

Se analisarmos a expansão colonial europeia de um ponto de vista eurocêntrico, o que obtemos é um quadro em que as origens do chamado sistema-mundo capitalista são produzidas sobretudo pela concorrência entre os diversos impérios europeus. O principal motivo para esta expansão foi encontrar rotas mais curtas para o Oriente, o que, acidentalmente, levou à chamada descoberta e posterior colonização das Américas por parte da Espanha. Segundo este ponto de vista, o sistema-mundo capitalista seria essencialmente um sistema económico que determina o comportamento dos principais actores sociais através da lógica económica da obtenção de lucro, manifestando-se na extraç̧ão de excedentes e na incessante acumulação de capital à escala mundial. Além disso, o conceito de capitalismo subjacente a esta perspectiva privilegia as relações económicas sobre as relações sociais. Por conseguinte, a transformação das relações de produção origina uma nova estrutura de classes típica do capitalismo, em contraste com outros sistemas sociais e outras formas de dominação. A análise de classes e as transformações estruturais no âmbito económico são privilegiadas em relação a outras relações de poder.

Sem negar a importância da permanente acumulação de capital à escala mundial e a existência de uma estrutura de classes específica do capitalismo global, coloco a seguinte questão epistémica: Como seria o sistema-mundo se deslocássemos o locus da enunciação, transferindo-o do homem europeu para as mulheres indígenas das Américas, como, por exemplo, Rigoberta Menchu da Guatemala ou Domitilia da Bolívia? Não tenho a pretensão de defender ou representar a perspectiva destas mulheres indígenas. $\mathrm{O}$ que pretendo fazer é deslocar o lugar a partir do qual estes paradigmas são pensados. A primeira ilação a tirar do 
deslocamento da nossa geopolítica do conhecimento é que aquilo que chegou às Américas nos finais do século XVI não foi apenas um sistema económico de capital e trabalho destinado à produção de mercadorias para serem vendidas com lucro no mercado mundial. Essa foi uma parte fundamental, ainda que não a única, de um "pacote" mais complexo e enredado. $\mathrm{O}$ que chegou às Américas foi uma enredada estrutura de poder mais ampla e mais vasta, que uma redutora perspectiva económica do sistema-mundo não é capaz de explicar. Vendo a partir do lugar estrutural de uma mulher indígena das Américas, o que então surgiu foi um sistema-mundo mais complexo do que aquele que é retratado pelos paradigmas da economia política e pela análise do sistema-mundo. Às Américas chegou o homem heterossexual/branco/patriarcal/cristão/militar/capitalista/ europeu, com as suas várias hierarquias globais enredadas e coexistentes no espaço e no tempo, as quais, por motivos de clareza da presente exposição, passarei em seguida a enumerar como se fossem independentes umas das outras:

1) uma específica formação de classes de âmbito global, em que diversas formas de trabalho (escravatura, semi-servidão feudal, trabalho assalariado, pequena produção de mercadorias) irão coexistir e ser organizadas pelo capital enquanto fonte de produção de mais`valias através da venda de mercadorias no mercado mundial com vista ao lucro;

2) uma divisão internacional do trabalho em centro e periferia, em que o capital organizava o trabalho na periferia de acordo com formas autoritárias e coercivas (Wallerstein, 1974);

3) um sistema interestatal de organizações político-militares controladas por homens europeus e institucionalizadas em administrações coloniais (Wallerstein, 1979);

4) uma hierarquia étnico-racial global que privilegia os povos europeus relativamente aos não-europeus (Quijano, 1993, 2000);

5) uma hierarquia global que privilegia os homens relativamente às mulheres e o patriarcado europeu relativamente a outros tipos de relação entre os sexos (Spivak, 1988; Enloe, 1990); 
6) uma hierarquia sexual que privilegia os heterossexuais relativamente aos homossexuais e lésbicas (e é importante recordar que a maioria dos povos indígenas das Américas não via a sexualidade entre homens como um comportamento patológico nem tinha qualquer ideologia homofóbica);

7) uma hierarquia espiritual que privilegia os cristãos relativamente às espiritualidades não-cristãs/não-europeias institucionalizadas na globalização da igreja cristã (católica e, posteriormente, protestante);

8) uma hierarquia epistémica que privilegia a cosmologia e o conhecimento ocidentais relativamente ao conhecimento e às cosmologias não-ocidentais, e institucionalizada no sistema universitário global (Mignolo,1995, 2000; Quijano, 1991);

9) uma hierarquia linguística entre as línguas europeias e não-europeias que privilegia a comunicação e a produção de conhecimento e de teorias por parte das primeiras, e que subalterniza as últimas exclusivamente como produtoras de folclore ou cultura, mas não de conhecimento/teoria(Mignolo, 2000).

Não é por acaso que a conceptualização do sistema-mundo feita segundo perspectivas descoloniais do Sul vai pôr em causa as tradicionais conceptualizações produzidas por pensadores do Norte. Na esteira do sociólogo peruano Aníbal Quijano (1991, 1998, 2000), poderíamos conceptualizar o actual sistema-mundo como um todo histórico-estrutural heterogêneo dotado de uma matriz de poder específica a que chama "matriz de poder colonial" "patrón de poder colonial"). Esta afecta todas as dimensões da existência social, tais como a sexualidade, a autoridade, a subjectividade e o trabalho (Quijano, 2000). O século XVI lança uma nova matriz de poder colonial que, nos finais do século XIX, havia alastrado a todo o planeta. Indo um passo além de Quijano, conceptualizo a colonialidade do poder como um enredamento ou, para usar o conceito das feministas norte-americanas de Terceiro Mundo, como uma interseccionalidade (Crenshaw, 1989; Fregoso, 2003) de múltiplas e heterogéneas hierarquias globais ("heterarquias") de formas de dominação e exploração sexual, política, epistémica, 
económica, espiritual, linguística e racial, em que a hierarquia étnico-racial do fosso cavado entre o europeu e o não-europeu reconfigura transversalmente todas as restantes estruturas globais de poder. $\mathrm{O}$ que a perspectiva da "colonialidade do poder" tem de novo é o modo como a ideia de raça e racismo se torna o princípio organizador que estrutura todas as múltiplas hierarquias do sistema-mundo (Quijano, 1993). Por exemplo, as diferentes formas de trabalho que se encontram articuladas com a acumulação de capital no âmbito mundial são distribuídas de acordo com esta hierarquia racial; o trabalho coercivo (ou barato) é feito por pessoas não-europeias situadas na periferia, e o "trabalho assalariado livre" situa-se no centro. A hierarquia global das relações entre os sexos também é afectada pela raça: ao contrário dos patriarcados pré-europeus em que todas as mulheres eram inferiores aos homens, na nova matriz de poder colonial algumas mulheres (de origem europeia) possuem um estatuto mais elevado e um maior acesso aos recursos do que alguns homens (de origem não-europeia). A ideia de raça organiza a população mundial segundo uma ordem hierárquica de povos superiores e inferiores que passa a ser um princípio organizador da divisão internacional do trabalho e do sistema patriarcal global. Contrariamente ao que afirma a perspectiva eurocêntrica, a raça, a diferença sexual, a sexualidade, a espiritualidade e a epistemologia não são elementos que acrescem às estruturas económicas e políticas do sistema-mundo capitalista, mas sim uma parte integrante, entretecida e constitutiva desse amplo "pacote enredado" a que se chama sistema-mundo patriarcal/capitalista/colonial/moderno europeu (Grosfoguel, 2002). O patriarcado europeu e as noções europeias de sexualidade, epistemologia e espiritualidade foram exportadas para o resto do mundo através da expansão colonial, transformadas assim nos critérios hegemónicos que iriam racializar, classificar e patologizar a restante população mundial de acordo com uma hierarquia de raças superiores e inferiores. 
Esta conceptualização tem enormes implicações, a que aqui não posso fazer senão uma breve menção:

1) A velha ideia de que, no âmbito do Estado-nação, as sociedades se desenvolvem de acordo com uma evolução linear que vai de modos de produção pré-capitalistas para o modo capitalista, encontra-se ultrapassada. Estamos todos envolvidos num sistema-mundo capitalista que articula diferentes formas de trabalho de acordo com a classificação racial da população mundial (Quijano 2000; Grosfoguel, 2002);

2) O velho paradigma marxista da infra-estrutura e da superestrutura é substituído por uma estrutura histórico-heterogénea (Quijano, 2000), ou "heterarquia" (Kontopoulos, 1993), ou seja, uma enredada articulação de múltiplas hierarquias, na qual a subjectividade e o imaginário social não decorrem das estruturas do sistema-mundo mas são, isso sim, constituintes desse sistema (Grosfoguel, 2002). Nesta conceptualização, raça e racismo não são superestruturais ou instrumentais para uma lógica preponderante de acumulação capitalista; são constitutivos da acumulação capitalista à escala mundial. A "matriz de poder colonial” é um princípio organizador que envolve o exercício da exploração e da dominação em múltiplas dimensões da vida social, desde a económica, sexual ou das relações de género, até às organizações políticas, estruturas de conhecimento, instituições estatais e agregados familiares (Quijano, 2000).

3) A velha divisão entre cultura e economia política, tal como é apresentada nos estudos pós-coloniais e nas abordagens político-económicas, é superada (Grosfoguel, 2002). Os estudos pós-coloniais conceptualizam o sistema-mundo capitalista como sendo constituído principalmente pela cultura, ao passo que a economia política vê nas relações económicas o factor determinante primordial. $\mathrm{Na}$ abordagem da "colonialidade do poder", a questão de saber o que vem primeiro, "a cultura ou a economia", é um falso dilema, um dilema do ovo e da galinha, que turva a complexidade do sistema-mundo capitalista (Grosfoguel, 2002). 
4) Dizer colonialidade não é o mesmo que dizer colonialismo. Não se trata de uma forma decorrente nem antecedente da modernidade. Colonialidade e modernidade constituem duas faces de uma mesma moeda. Da mesma maneira que a revolução industrial europeia foi possível graças às formas coercivas de trabalho na periferia, as novas identidades, direitos, leis e instituições da modernidade, de que são exemplo os Estados`nação, a cidadania e a democracia, formaram-se durante um processo de interacção colonial, e também de dominação/exploração, com povos não-ocidentais.

5) Chamar "capitalista" ao actual sistema-mundo é, no mínimo, equívoco. Tendo em conta o eurocêntrico "senso comum" hegemónico, a partir do momento em que usamos a palavra "capitalismo" as pessoas pensam de imediato que estamos a falar de "economia". No entanto, o "capitalismo" é apenas uma das múltiplas e enredadas constelações da matriz de poder colonial do "sistema-mundo patriarcal/capitalista/colonial/moderno europeu”. É importante, mas não a única. Dado o seu enredamento com outras relações de poder, destruir os aspectos capitalistas do sistema-mundo não seria suficiente para destruir o actual sistema-mundo. Para o transformar seria essencial destruir um todo históricoestrutural heterogéneo a que se chama a "matriz de poder colonial" do "sistemamundo".

6) A descolonização e a libertação anticapitalistas não podem ser reduzidas a uma única dimensão da vida social. É necessária uma transformação mais ampla das hierarquias sexuais, de género, espirituais, epistémicas, económicas, políticas, linguísticas e raciais do sistema-mundo colonial/moderno. A perspectiva da "colonialidade do poder" desafia-nos a reflectir sobre as mudanças e transformações sociais de uma forma que não seja redutora. 


\section{Do colonialismo global à colonialidade global}

Não podemos pensar na descolonização como a conquista do poder sobre as fronteiras jurídico-políticas de um Estado, ou seja, como a aquisição de controlo sobre um único Estado-nação (Grosfoguel, 1996). A velha emancipação nacional e as estratégias socialistas de tomada do poder ao nível do Estado-nação não são suficientes, porque a colonialidade global não é redutível à presença ou ausência de uma administração colonial (Grosfoguel, 2002) nem às estruturas políticoeconómicas do poder. Um dos mais poderosos mitos do século XX foi a noção de que a eliminação das administrações coloniais conduzia à descolonização do mundo, o que originou o mito de um mundo "pós-colonial". As múltiplas e heterogéneas estruturas globais, implantadas durante um período de 450 anos, não se evaporaram juntamente com a descolonização jurídico-política da periferia ao longo dos últimos 50 anos. Continuamos a viver sob a mesma "matriz de poder colonial". Com a descolonização jurídico-política saímos de um período de "colonialismo global" para entrar num período de "colonialidade global". Embora as "administrações coloniais" tenham sido quase todas erradicadas e grande parte da periferia se tenha organizado politicamente em Estados independentes, os povos não-europeus continuam a viver sob a rude exploração e dominação europeia/euro-americana. As antigas hierarquias coloniais, agrupadas na relação europeias versus não-europeias, continuam arreigadas e enredadas na "divisão internacional do trabalho" e na acumulação do capital à escala mundial (Quijano, 2000; Grosfoguel, 2002).

É aqui que reside a pertinência da distinção entre "colonialismo" e "colonialidade". A colonialidade permite-nos compreender a continuidade das formas coloniais de dominação após o fim das administrações coloniais, produzidas pelas culturas coloniais e pelas estruturas do sistema-mundo capitalista moderno/colonial. A expressão "colonialidade do poder" designa um processo fundamental de estruturação do sistema-mundo moderno/colonial, que articula os lugares periféricos da divisão internacional do trabalho com a hierarquia étnico-racial global e com a inscrição de migrantes do Terceiro Mundo 
na hierarquia étnico-racial das cidades metropolitanas globais. Os Estados-nação periféricos e os povos não-europeus vivem hoje sob o regime da "colonialidade global" imposto pelos Estados Unidos, através do Fundo Monetário Internacional (FMI), do Banco Mundial (BM), do Pentágono e da OTAN. As zonas periféricas mantêm-se numa situação colonial, ainda que já não estejam sujeitas a uma administração colonial.

A palavra "colonial" não designa apenas o "colonialismo clássico" ou um "colonialismo interno", nem pode ser reduzida à presença de uma "administração colonial”. Quijano estabelece uma distinção entre colonialismo e colonialidade. Eu uso a palavra "colonialismo" para me referir a "situações coloniais" impostas pela presença de uma administração colonial, como é o caso do período do colonialismo clássico, e, na esteira de Quijano, uso a designação "colonialidade" para me referir a "situações coloniais" da actualidade, em que as administrações coloniais foram praticamente erradicadas do sistema-mundo capitalista. Por "situações coloniais" entendo a opressão/exploração cultural, política, sexual e económica de grupos

étnicos/racializados subordinados por parte de grupos étnico-raciais dominantes, com ou sem a existência de administrações coloniais. Cinco séculos de expansão e dominação colonial europeia criaram uma divisão internacional do trabalho entre europeus e não-europeus, que se encontra reproduzida no que se chama a actual fase "pós-colonial" do sistema-mundo capitalista (Wallerstein, 1979, 1995). Actualmente, as zonas centrais da economia-mundo capitalista coincidem com sociedades predominantemente brancas/europeias/euro-americanas, tais como a Europa Ocidental, o Canadá, a Austrália e os Estados Unidos, enquanto as zonas periféricas coincidem com povos não-europeus outrora colonizados. O Japão é a única excepção que confirma a regra, na medida em que nunca foi colonizado nem dominado pelos europeus e, à semelhança do Ocidente, desempenhou um papel activo na construção do seu próprio império colonial. A China, embora nunca colonizada na sua totalidade, viu-se periferizada pelo uso de entrepostos coloniais como Hong Kong e Macau, e por intervenções militares directas. 
A mitologia da "descolonização do mundo" tolda as continuidades entre o passado colonial e as actuais hierarquias coloniais/raciais globais, além de que contribui para a invisibilidade da "colonialidade" no momento presente. Durante os últimos cinquenta anos, os Estados periféricos que hoje são oficialmente independentes, alinhando com os discursos liberais egocêntricos dominantes (Wallerstein, 1991a, 1995), construíram ideologias de “identidade nacional", "desenvolvimento nacional" e "soberania nacional" que produziram uma ilusão de "independência", "desenvolvimento" e "progresso". Contudo, os seus sistemas económicos e políticos foram moldados pela sua posição subordinada num sistema-mundo capitalista que se organiza em torno de uma divisão hierárquica internacional do trabalho (Wallerstein, 1979, 1984, 1995). Os múltiplos e heterogéneos processos do sistema-mundo, juntamente com a predominância das culturas eurocêntricas (Said, 1979; Wallerstein, 1991b, 1995; Lander, 1998; Quijano, 1998; Mignolo, 2000), constituem uma "colonialidade global" entre, por um lado, povos europeus/euro-americanos e, por outro, povos não-europeus. Por conseguinte, a "colonialidade" interliga-se com a divisão internacional do trabalho, mas não pode ser reduzida apenas a isso. A hierarquia étnico-racial global de europeus/nãoeuropeus é parte integrante do desenvolvimento da divisão internacional do trabalho no sistema-mundo capitalista (Wallerstein, 1983; Quijano, 1993; Mignolo, 1995). Nestes tempos de "pós-independência”, o eixo "colonial” entre europeus/euro-americanos e não-europeus inscreve-se não só nas relações de exploração (entre capital e trabalho) e nas relações de dominação (entre Estados metropolitanos e Estados periféricos), mas também na produção de subjectividades e de conhecimento. Resumindo, parte do mito eurocêntrico é que vivemos numa chamada era "pós"-colonial e que o mundo e, em especial, os centros metropolitanos, não necessitam de descolonização. Segundo esta definição convencional, a colonialidade é reduzida à presença de administrações coloniais. Porém, como comprovou o trabalho do sociólogo peruano Aníbal Quijano (1993, 1998, 2000) com a sua perspectiva da "colonialidade do poder", continuamos a viver num mundo colonial e temos de nos libertar das formas estreitas de pensar as relações coloniais, de modo a concretizar esse inacabado e incompleto sonho do século XX que é a descolonização. Isto obriga-nos a examinar novas alternativas 
coloniais utópicas, que vão além dos fundamentalismos eurocêntrico e "terceiromundista”.

\section{Pós-colonialidade e sistemas-mundo: um apelo ao diálogo}

Repensar o mundo colonial/moderno a partir da diferença colonial altera importantes pressupostos dos nossos paradigmas. Aqui, gostaria de me centrar nas implicações que a perspectiva da "colonialidade do poder" tem para o sistemamundo e para os paradigmas pós-coloniais. A maioria das análises do sistemamundo debruçam-se sobre a forma como a divisão internacional do trabalho e as lutas militares geopolíticas são elementos constitutivos dos processos de acumulação capitalista à escala mundial. Embora use esta abordagem como ponto de partida, pensar a partir da diferença colonial obriga-nos a considerar com maior seriedade as estratégias ideológico-simbólicas, bem como a cultura colonial/racista do mundo colonial/moderno. Recentemente, a análise do sistemamundo desenvolveu o conceito de geocultura para se referir às ideologias globais. No entanto, o uso do termo "geocultura" na abordagem do sistema-mundo enquadra-se no paradigma marxista da infra-estrutura/superestrutura. Contrariamente a esta conceptualização, considero que as estratégias ideológicosimbólicas globais e a cultura colonial/racista, juntamente com os processos de acumulação capitalista e o sistema interestatal, são constitutivas das relações centro/periferia à escala mundial. Estas diferentes estratégias e processos formam uma heterarquia (Kontopoulos, 1993) de hierarquias heterogéneas, complexas e enredadas que não são passíveis de explicação através do paradigma infra-estrutura/superestrutura.

A pós-colonialidade e a abordagem do sistema-mundo partilham entre si uma crítica ao desenvolvimentismo, às formas eurocêntricas de conhecimento, às desigualdades entre os sexos, às hierarquias raciais e aos processos culturais/ideológicos que fomentam a subordinação da periferia no sistemamundo capitalista. Contudo, as visões críticas permitidas por uma e outra 
abordagem dão ênfase a diferentes causas determinantes. Enquanto as críticas pós-coloniais salientam a cultura colonial, a abordagem do sistema-mundo sublinha a acumulação interminável de capital à escala mundial. E se, por um lado, as críticas pós-coloniais dão ênfase à agência, por outro, a abordagem do sistema-mundo enfatiza as estruturas. Alguns académicos da teoria pós-colonial, como, por exemplo, Gayatri Spivak (1998), reconhecem a importância da divisão internacional do trabalho enquanto elemento constitutivo do sistema capitalista. Outros, porém, partidários da abordagem do sistema-mundo, como, por exemplo, Immanuel Wallerstein, reconhecem a importância de processos culturais como o racismo e o sexismo enquanto algo de inerente ao capitalismo histórico. No entanto, no geral, os dois campos permanecem divididos no que diz respeito às oposições binárias cultura versus economia e agência versus estrutura. Isto devese, em parte, ao legado das "duas culturas" do saber ocidental, que divide as ciências das humanidades, uma divisão por sua vez assente no dualismo cartesiano que sobrepõe o espírito à matéria.

Salvo raras excepções, a maioria dos teóricos pós-coloniais vem do campo das humanidades, de áreas como a literatura, a retórica e os estudos culturais. Apenas uma pequena parte dos académicos do campo da pós-colonialidade vem das ciências sociais, nomeadamente da antropologia. Por outro lado, os académicos da análise do sistema-mundo são, na sua maioria, provenientes de disciplinas das ciências sociais, como a sociologia, a antropologia, as ciências políticas e a economia. Entre estes, são poucos os que vêm das humanidades - à excepção dos historiadores, que costumam ter maior afinidade com a abordagem do sistema-mundo -, e também são muito poucos os que vêm da literatura. Salientei as disciplinas que predominam em ambas as abordagens porque considero que estas fronteiras disciplinares são constitutivas de algumas diferenças teóricas existentes entre uma e outra. 
A crítica pós-colonial caracteriza o sistema capitalista enquanto sistema cultural. Estes teóricos acreditam que a cultura é o factor constitutivo que determina as relações económicas e políticas no capitalismo global (Said, 1979). Por outro lado, a maioria dos académicos do sistema-mundo salienta a importância das relações económicas à escala mundial como factor constitutivo do sistema-mundo capitalista. As relações culturais e políticas são conceptualizadas quer como instrumento, quer como epifenómeno, dos processos de acumulação capitalista. $\mathrm{O}$ facto é que os teóricos do sistema-mundo sentem dificuldades em teorizar a cultura, enquanto os teóricos pós-coloniais têm dificuldade em conceptualizar os processos político-económicos. Paradoxal é que muitos académicos do sistemamundo reconheçam a importância da cultura, mas não saibam o que fazer com ela ou como o expressar de uma forma não redutora; por seu lado, muitos acadêmicos pós-coloniais reconhecem a importância da economia política, mas não sabem como a integrar na análise cultural sem reproduzir um reducionismo de tipo "culturalista". Assim, a bibliografia produzida de uma e outra banda oscila entre o perigo do reducionismo económico e o perigo do culturalismo. Tanto os Estudos Pós-Coloniais como a Análise do Sistema-Mundo estão a necessitar de uma intervenção descolonial.

Eu sugiro que a dicotomia cultura versus economia é um dilema "do ovo e da galinha", ou seja, um falso dilema que nasce daquilo a que Immanuel Wallerstein chamou o legado do liberalismo do século XIX (Wallerstein, 1991a: 4). Este legado implica que se faça uma separação da economia, política, cultura e sociedade em áreas autónomas. Segundo Wallerstein, a construção destas área s "autónomas" e a sua materialização em domínios de conhecimento separados, tais como a ciência política, a sociologia, a antropologia e a economia, nas ciências sociais, assim como as diferentes disciplinas das humanidades, são o pernicioso resultado do liberalismo enquanto geocultura do sistema-mundo moderno. Numa apreciação crítica da análise do sistema-mundo, Wallerstein afirma que A análise do sistema-mundo pretende ser uma crítica à ciência social do século XIX. 
Porém, é uma crítica incompleta, inacabada, pois ainda não conseguiu encontrar uma forma de ultrapassar o mais persistente (e enganoso) legado da ciência social do século XIX - a divisão da análise social em três áreas, três lógicas, três níveis o económico, o político e o sociocultural. Este trio atravessa-se-nos no caminho, sólido como granito, a bloquear o nosso avanço intelectual. Muitos consideram־no insatisfatório, mas, a meu ver ainda ninguém arranjou maneira de prescindir dessa linguagem e respectivas implicações, algumas das quais correctas, mas a maioria delas talvez não. (1991a: 4) [...] todos nós recorremos ao uso da linguagem das três áreas em praticamente tudo o que escrevemos. É o momento de tentar enfrentar seriamente a questão. [...] estamos a ir atrás de falsos modelos e a comprometer a nossa argumentação quando continuamos a usar essa linguagem. É urgente começarmos a elaborar modelos alternativos. (1991a: 271)

Há que desenvolver uma nova linguagem descolonial para representar os complexos processos do sistema-mundo colonial/moderno, sem estarmos dependentes da velha linguagem liberal destas três áreas. Por exemplo, o facto de os teóricos do sistema-mundo caracterizarem o sistema-mundo moderno como uma economia-mundo leva muitas pessoas a pensar erroneamente que a análise do sistema-mundo consiste em analisar a chamada "lógica económica" do sistema. É exactamente este tipo de interpretação que Wallerstein tenta evitar na sua crítica a estes três domínios autónomos. Contudo, como admite o próprio Wallerstein, a linguagem usada pela análise do sistema-mundo ainda está presa à velha linguagem da ciência social do século XIX e prescindir desta linguagem é um enorme desafio. E se o capitalismo for uma economia-mundo, não no sentido limitado de um sistema económico, mas no sentido de sistema histórico que Wallerstein define como "[...] uma rede integrada de processos económicos, políticos e culturais, cuja so ma garante a coesão do sistema" (Wallerstein, 1991a: 230)? 
Precisamos de encontrar novos conceitos e uma nova linguagem se quisermos explicar o complexo enredamento das hierarquias de género, raciais, sexuais e de classe existentes no interior dos processos geopolíticos, geoculturais e geoeconómicos do sistema-mundo colonial/moderno, em que a incessante acumulação de capital é afectada por - e integrada em, e constitutiva de, e constituída por - essas hierarquias. A fim de encontrar uma nova linguagem descolonial para esta complexidade, precisamos de "sair" dos nossos paradigmas, abordagens, disciplinas e campos. Proponho que examinemos a noção metateórica de "heterarquias" desenvolvida pelo teórico social, sociólogo e filósofo grego Kyriakos Kontopoulos (1993) e também a noção de "colonialidade do poder" desenvolvida por Aníbal Quijano (1991, 1993, 1998).

O pensamento heterárquico (Kontopoulos, 1993) é uma tentativa de conceptualizar as estruturas sociais através de uma nova linguagem que rompa com o paradigma liberal da ciência social do século XIX. A velha linguagem das estruturas sociais é uma linguagem de sistemas fechados, ou seja, de uma lógica única e abrangente que determina uma hierarquia única. Definir um sistema social como uma "hierarquia aninhada", como propôs Wallerstein no relatório da Comissão Gulbenkian "Para Abrir as Ciências Sociais", compromete a abordagem do sistema-mundo ao continuar a usar um modelo metateórico que corresponde a sistemas fechados, que é precisamente o oposto daquilo que a abordagem do sistema-mundo tenta fazer.

Ao invés disso, as heterarquias fazem־nos transpor as hierarquias fechadas rumo a uma linguagem de complexidade, a sistemas abertos e a um enredamento de múltiplas e heterogéneas hierarquias, níveis estruturais e lógicas estruturantes. A noção de "lógica" é aqui redefinida para referir o enredamento heterogéneo das estratégias de múltiplos agentes. A ideia é a seguinte: não existe nem lógica autónoma nem uma única lógica, mas sim múltiplos, heterogéneos, enredados e complexos processos inseridos numa única realidade histórica. A noção de 
enredamento é fundamental aqui e está próxima da noção de sistemas históricos de Wallerstein, entendidos enquanto "redes integradas de processos económicos, políticos e culturais". A partir do momento em que as relações hierárquicas múltiplas são vistas como enredadas, segundo Kontopoulos, ou integradas, segundo Wallerstein, deixam de existir lógicas ou domínios autónomos. A noção de uma lógica única corre o risco de reducionismo, o que é contrário à ideia de sistemas complexos, e a noção de lógicas múltiplas corre o risco de dualismo. A solução para estas questões ontológicas (o dilema reducionismo/dualismo) do pensamento heterárquico é superar a oposição binária monismo/dualismo, no sentido de um materialismo emergentista que implica múltiplos processos enredados a diferentes níveis estruturais, inseridos numa única realidade material histórica (que inclui o simbólico-ideológico como parte dessa mesma realidade material). As heterarquias continuam a usar a noção de "lógica" apenas para fins analíticos, de modo a estabelecer determinadas distinções ou para tornar abstractos certos processos que, uma vez integrados ou enredados num processo histórico concreto, adquirem um efeito e um significado estruturais diferentes. O pensamento heterárquico fornece uma linguagem para dizer aquilo a que Immanuel Wallerstein chama um novo modo de pensamento capaz de romper com as ciências sociais do século XIX liberal e centrar-se em sistemas históricos complexos.

A noção de "colonialidade do poder" também é útil em termos de descolonização do dilema cultura versus economia. O trabalho de Quijano oferece uma nova forma de pensar sobre este dilema, a qual ultrapassa os limites tanto da análise pós-colonial como da análise do sistema-mundo. Na América Latina, a maioria dos teóricos dependentistas privilegiam as relações económicas em processos sociais, em detrimento das determinações de ordem cultural e ideológica. A escola dependentista percepcionou a cultura como sendo um factor instrumental nos processos de acumulação capitalista. Em muitos aspectos, a análise dos dependentistas e a análise do sistema-mundo reproduziram parte do reducionismo económico das abordagens marxistas ortodoxas. Isto causou dois 
problemas: em primeiro lugar, um subestimar das hierarquias coloniais/raciais; e, em segundo lugar, um empobrecimento analítico que se revelou incapaz de explicar as complexidades dos processos político-económicos heterárquicos globais.

As ideias dependentistas têm de ser compreendidas enquanto parte da longue durée das ideias da modernidade na América Latina. O desenvolvimento nacional autónomo é um tema ideológico central do sistema-mundo moderno desde finais do século XVIII. Os dependentistas reproduziram a ilusão de que o desenvolvimento e a organização racional podem ser alcançados por meio do controlo do Estado-nação. Isto veio contradizer a posição segundo a qual desenvolvimento e subdesenvolvimento são o resultado de relações estruturais no interior do sistema-mundo capitalista. Não obstante definirem o capitalismo como um sistema global que está para além do Estado-nação, os dependentistas ainda acreditavam ser possível quebrar o vínculo, rompendo com o sistemamundo ao nível do Estado--nação (Frank, 1969: 11, 104, 150, capítulo 25). Isto significava que um processo revolucionário socialista de âmbito nacional poderia isolar o país em relação ao sistema global. Contudo, tal como sabemos actualmente, é impossível transformar um sistema que opere à escala global privilegiando o controlo/administração do Estado-nação (Wallerstein, 1992b). Nenhum tipo de controlo "racional" do Estado-nação poderá, por si, alterar a localização de um determinado país na divisão internacional do trabalho. O planeamento e o controlo "racional" do Estado-nação contribuem para a ilusão desenvolvimentista da eliminação das desigualdades do sistema-mundo capitalista ao nível do Estado-nação.

No sistema-mundo capitalista, um Estado-nação periférico pode passar por transformações na sua forma de incorporação na economia-mundo capitalista, e uma minoria desses Estados pode mesmo deslocar-se para uma 
posição semiperiférica. No entanto, romper com ou transformar todo o sistema ao nível do Estado-nação está completamente fora do leque das suas possibilidades (Wallerstein, 1992a, 1992b). Por isso, um problema global não pode ter uma solução nacional. Não se trata de negar a importância das intervenções políticas ao nível do Estado-nação. O importante será não reificar o Estado-nação e compreender os limites das intervenções políticas, a este nível, para a transformação a longo prazo de um sistema que opera à escala mundial. Embora continue a ser uma importante instituição do Capitalismo Histórico, o Estado-nação é um espaço limitado para transformações políticas e sociais radicais. Para serem capazes de intervir eficazmente no sistema-mundo capitalista, as agências colectivas da periferia precisam de ter um âmbito global. Os conflitos sociais ocorridos em níveis situados abaixo e acima do Estado-nação são espaços estratégicos de intervenção política frequentemente ignorados quando o foco dos movimentos privilegia o Estado-nação. Para que a intervenção política seja eficaz, as ligações locais e globais dos movimentos sociais assumem uma importância crucial. Os dependentistas não tiveram isto em conta, devido, em parte, à sua tendência para privilegiar o Estado-nação como unidade de análise e também à ênfa se economicista das suas abordagens. Isto teve terríveis consequências práticas para a esquerda da América Latina e para a credibilidade do projecto político dependentista. 
Para a maioria dos dependentistas e dos analistas do sistema-mundo, a "economia" era a esfera privilegiada da análise social. Categorias como "diferença sexual" e "raça" eram frequentemente ignoradas e, quando usadas, eram reduzidas (instrumentalizadas) a interesses económicos ou de classe. Quijano (1993) é uma das poucas excep̧̧ões a esta crítica. A "colonialidade do poder" é um conceito que tenta integrar, como parte de um processo estrutural heterogéneo, as múltiplas relações em que os processos culturais, políticos e económicos se enredam com o capitalismo enquanto sistema histórico. Quijano usa a noção de "heterogeneidade estrutural", muito próxima da noção de "heterarquia" acima discutida. À semelhança da análise do sistema-mundo, a noção de "colonialidade" conceptualiza o processo de colonização das Américas e a constituição de uma economia-mundo capitalista como fazendo parte do mesmo enredado processo. Contudo, ao contrário da abordagem do sistema-mundo, a "heterogeneidade estrutural" de Quijano implica a construção de uma hierarquia étnico-racial global que é, temporal e espacialmente, coeva da constituição de uma divisão internacional do trabalho com relações centro-periferia à escala mundial. Desde o início da formação do sistema-mundo capitalista, a acumulação incessante de capital esteve sempre enredada com ideologias racistas, homofóbicas e sexistas. A expansão colonial europeia foi conduzida por homens europeus heterossexuais. Aonde quer que chegassem, traziam consigo os seus preconceitos culturais e formavam estruturas heterárquicas de desi- 
gualdade sexual, de género, de classe e raciais. Deste modo, no "capitalismo histórico" - entendido como "sistema heterárquico" ou "estrutura heterogénea" - o processo de incorporação periférica na acumulação incessante de capital foi sendo constituído por, e enredado com, hierarquias e discursos homofóbicos, sexistas e racistas. Ao contrário da análise do sistema-mundo, Quijano sublinha, com a sua noção de "colonialidade do poder", a ideia de que não existe uma lógica abrangente de acumulação capitalista capaz de instrumentalizar as divisões étnico-raciais e que seja anterior à formação de uma cultura colonial, eurocêntrica global. A abordagem "instrumentalista" da maior parte da análise do sistema-mundo é redutora e permanece presa à velha linguagem da ciência social do século XIX. Para Quijano, o racismo é constitutivo e indissociável da divisão internacional do trabalho e da acumulação capitalista à escala mundial. A noção de "heterogeneidade estrutural" implica que múltiplas formas de trabalho coexistam dentro de um único processo histórico. Contrariamente ao que sustentam as abordagens marxistas ortodoxas, não existe u ma sucessão linear dos modos de produção (escravatura, feudalismo, capitalismo, etc). De uma perspectiva periférica como é a latino-a mericana, e de um modo geral, estas formas de trabalho articularam-se, todas elas, simultaneamente no tempo e enredaram-se no espaço, variando entre, por um lado, formas "livres" de trabalho atribuídas no centro ou a populações de origem europeia, e por outro lado formas "coercivas" de trabalho entregues à periferia ou a popula- 
ções de origem não-europeia. A acumulação capitalista à escala mundial opera em simultâneo através de diversas formas de trabalho que são divididas, organizadas e atribuídas de acordo com a racionalidade racista eurocêntrica da "colonialidade do poder". Além disso, para Quijano, não existe uma teleologia linear entre as diferentes formas de acumulação capitalista (primitiva, absoluta e relativa, segundo a ordenação da análise marxista eurocêntrica). Segundo este autor, as múltiplas formas de acumulação também são temporalmente coevas. Enquanto tendência a longo prazo, as formas "violentas" (a que o marxismo eurocêntrico chama "primitivas") de acumulação de capital são predominantes na periferia não-europeia, enquanto as formas "absolutas" de acumulação predominam nas zonas de trabalho "livre" do centro europeu.

O segundo problema decorrente do facto de a visão dependentista subestimar as dinâmicas culturais e ideológicas é que isso empobreceu a sua própria abordagem político-económica. Tanto as estratégias ideológico-simbólicas como as formas eurocêntricas de conhecimento são constitutivas da economia política do sistema -mundo capitalista. As estratégias simbólicas/ideológicas são um importante processo estruturante das relações centro-periferia no sistema-mundo capitalista. Os Estados centrais, por exemplo, desenvolvem estratégias ideológico-si mbólicas ao incentivar formas de conhecimento "ocidentalistas" (Mignolo, 1995) que privilegiam o Ocidente, ou "Oeste em detrimento do Resto". Isto é claramente visível em 
discursos desenvolvimentistas que, no decurso dos últimos cinquenta anos, se tornaram uma forma de conhecimento dito "científico". Este conhecimento privilegiou o "Ocidente" enquanto modelo de desenvolvimento. O discurso desenvolvimentista oferece uma fórmula colonial de como se assemelhar ao "Ocidente".

Apesar dos esforços para combater estas formas universalistas/ocidentalistas de conhecimento, os dependentistas viam este conhecimento como uma "superestrutura" ou o epifenómeno de uma "infra -estrutura económica", nunca considerando que ele fosse constitutivo da economia política da América Latina. A postulação de zonas periféricas, como a África ou a América Latina, como "regiões com problemas" ou com "um atrasado nível de desenvolvimento" dissimulou a responsabilidade europeia e euro-americana na exploração destes continentes. A postulação de regiões "patológicas" na periferia, por oposição aos chamados padrões "normais" de desenvolvimento do "Ocidente", justificou uma intervenção política e económica ainda mais intensa por parte das potências imperiais. Devido ao tratamento do "Outro" como "subdesenvolvido" e "a trasado", a exploração e a dominação por parte das metrópoles tornaram-se justificáveis em nome da "mis" são civilizadora".

A pretensa superioridade do saber europeu nas mais diversas áreas da vida foi um importante aspecto da colonialidade do poder no sistema-mundo colonial/moderno. Os saberes subalternos foram excluídos, omi- 
tidos, silenciados e/ou ignorados. Isto não é um apelo a uma missão fundamentalista ou essencialista de salvamento da autenticidade. Do que aqui se trata é de colocar a diferença colonial (Mignolo, 2000) no centro do processo de produção de conhecimento. Os saberes subalternos são aqueles que se situam na interseç̧ão do tradicional e do moderno. São formas de conhecimento híbridas e transculturais, não apenas no sentido tradicional de sincretismo ou mestizaje, mas no sentido das "armas miragrosas" de Aimé Césaire ou daquilo a que chamei "cumplicidade subversiva" (Grosfoguel, 1996) contra o sistema. Estas são formas de resistência que reinvestem de significado e transformam as formas dominantes de conhecimento do ponto de vista da racionalidade não-eurocêntrica das subjectividades subalternas, pensadas a partir de uma epistemologia de fronteira. Elas constituem aquilo a que Walter Mignolo (2000) chama uma crítica da modernidade baseada em experiências geopolíticas e memórias da colonialidade. Segundo Mignolo (2000), este é um espaço novo que merece ser alvo de maior exploração, como nova dimensão crítica da modernidade/colonialidade e, simultaneamente, como um espaço a partir do qual podem conceber-se novas utopias. Isto traz importantes implicações à produção de conhecimento. Iremos nós produzir um novo conhecimento que repita ou reproduza essa espécie de perspectiva dos olhos de deus que é a visão universalista e eurocêntrica? Dizer que a unidade de análise é o sistema-mundo, e não o Estado-nação, não equivale a uma visão neutra do 
mundo através do olhar divino. Acredito que a análise do sistema-mundo precisa de descolonizar a sua epistemologia, levando a sério o lado subalterno da diferença colonial: o lado da periferia, dos trabalhadores, das mulheres, dos indivíduos racializados/colonizados, dos homossexuais/lés bicas e dos movimentos anti-sistémicos que participam no processo de produção de conhecimento. Isto significa que, embora o sistema-mundo tome o mundo como unidade de análise, ele pensa a partir de uma determinada perspectiva no mundo. Contudo, a análise do sistema-mundo não encontrou uma maneira de incorporar os saberes subalternos nos processos de produção de conhecimento. Sem isto não pode haver uma descolonização do conhecimento nem uma utopística capaz de superar o eurocentrismo. A cumplicidade entre as ciências sociais e a colonialidade do poder na produção de conhecimento e dos desenhos imperiais globais requer novos lugares institucionais e não-institucionais, a partir dos quais o subalterno possa falar e ser ouvido.

\section{O pensamento de fronteira}

Até ao momento, a história do sistema-mundo patriarcal/capitalista/colonial/moderno tem privilegiado a cultura, o conhecimento e a epistemologia produzidos pelo Ocidente (Spivak, 1988; Mignolo, 2000). Nenhuma cultura no mundo permaneceu intacta perante a modernidade europeia. Não há, em absoluto, como estar fora deste sistema. O monologismo e o desenho 
monotópico global do Ocidente relacionam-se com outras culturas e povos a partir de uma posição de superioridade e são surdos às cosmologias e epistemologias do mundo não-ocidental.

A imposição do Cristianismo a fim de converter os chamados selvagens e bárbaros no século XVI, seguida da imposição do "fardo do homem branco" e da sua "missão civilizadora" nos séculos XVIII e XIX, da imposição do "projecto desenvolvimentista" no século XX e, mais recentemente, do projecto imperial das intervenções militares apoiadas na retórica da "democracia" e dos "direitos humanos" no século XXI, tudo isto foi imposto com recurso ao militarismo e à violência sob a retórica da modernidade, com o seu apelo a salvar o outro dos seus próprios barbarismos. Em face da imposição colonial eurocêntrica, surgem duas respostas: os nacionalismos e os fundamentalismos do Terceiro Mundo. O nacionalismo apresenta soluções eurocêntricas para um problema global eurocêntrico; reproduz uma colonialidade interna de poder dentro de cada Estado-nação e reifica o Estado-nação enquanto lugar privilegiado de mudança social (Grosfoguel, 1996). Os conflitos que ocorrem em níveis acima e abaixo do Esta do-nação não são tidos em consideração pelas estratégias políticas nacionalistas. Além do mais, as respostas nacionalistas ao capitalismo global reforçam o Estado-nação enquanto forma político-institucional por excelência do sistemamundo patriarcal/capitalista colonial/moderno. Neste sentido, o nacionalismo é cúmplice do pensamento e das estruturas políticas eurocêntricas. 
Por outro lado, os fundamentalismos terceiro-mundistas da mais variada espécie respondem com a retórica de um essencialista "puro espaço exterior" à modernidade, uma "absoluta exterioridade" relativamente a esta. São forças "modernas antimodernas" que reproduzem as oposições binárias do pensamento eurocêntrico. Se o pensamento eurocêntrico reivindica que a "democracia" é um atributo natural do Ocidente, os fundamentalismos do Terceiro Mundo aceitam esta premissa eurocêntrica e reivindicam que a democracia não tem nada que ver com o não-Ocidente. Ela é, assim, um atributo intrinsecamente europeu e imposto pelo Ocidente. Ambos negam o facto de muitos dos elementos que hoje consideramos parte da modernidade, como por exemplo a democracia, terem sido criados numa relação global entre o Ocidente e o não-Ocidente. Os europeus foram buscar muito do seu conhecimento utópico aos sistemas históricos não-ocidentais que encontraram nas colónias, apropriando-se deles e fazendo-os parte dessa sua modernidade eurocentrada. Os fundamentalismos do Terceiro Mundo respondem à imposição da modernidade eurocentrada enquanto desenho global/imperial com uma modernidade antimoderna que é tão eurocêntrica, hierárquica, autoritária e antidemocrática como aquela.

Uma das muitas soluções plausíveis para o dilema eurocêntrico versus fundamentalista é aquilo a que Walter Mignolo, inspirado em pensadores chicanos(as) como Gloria Anzaldúa (1987) e Jose David Saldívar (1997), 
chamou "pensamento crítico de fronteira" (Mignolo, 2000). O pensamento crítico de fronteira é a resposta epistémica do subalterno ao projecto eurocêntrico da modernidade. Ao invés de rejeitarem a modernidade para se recolherem num absolutismo fundamentalista, as epistemologias de fronteira subsumem/redefinem a retórica emancipatória da modernidade a partir das cosmologias e epistemologias do subalterno, localizadas no lado oprimido e explorado da diferença colonial, rumo a uma luta de libertação descolonial em prol de um mundo capaz de superar a modernidade eurocentrada. Aquilo que o pensamento de fronteira produz é uma redefinição/subsunção da cidadania e da democracia, dos direitos humanos, da humanidade e das relações económicas para lá das definições impostas pela modernidade europeia. O pensamento de fronteira não é um fundamentalismo antimoderno. É uma resposta transmoderna descolonial do subalterno perante a modernidade eurocêntrica.

Um bom exemplo disto mesmo é a luta zapatista no México. Os zapatistas não são fundamentalistas antimodernos, não rejeitam a democracia nem se remetem a uma espécie de fundamentalismo indígena. Pelo contrário, os zapatistas aceitam a noção de democracia, mas redefinem-na partindo da prática e da cosmologia indígena local, conceptualizando-a de acordo com a máxima "comandar obedecendo" ou "todos diferentes, todos iguais". O que parece ser um slogan paradoxal é, na verdade, uma redefinição crítica descolonial da democracia, recorrendo às práticas, 
cosmologias e epistemologias do subalterno. Isto leva-nos à questão de como transcender o monólogo imperial estabelecido pela modernidade europeia-eurocêntrica.

\section{A transmodernidade ou cosmopolitismo crítico enquanto projectos utópicos}

Um diálogo intercultural Norte-Sul não pode ser alcançado sem que ocorra uma descolonização das relações de poder no mundo moderno. Um diálogo de tipo horizontal, por contraposição com o diálogo vertical característico do Ocidente, exige uma transformação nas estruturas de poder globais. Não podemos presumir um consenso habermasiano ou uma relação igual entre culturas e povos globalmente extremados nos dois pólos da diferença colonial. Porém, podemos começar a imaginar mundos alternativos para lá do eurocentrismo e do fundamentalismo. A transmodernidade é o projecto utópico que o filósofo da libertação Enrique Dussel propõe para transcender a versão eurocêntrica da modernidade (Dussel, 2001). Ao contrário do projecto de Habermas, em que o objectivo é concretizar o incompleto e inacabado projecto da modernidade, a transmodernidade de Dussel visa concretizar o inacabado e incompleto projecto novecentista da descoloni zação. Em vez de uma única modernidade, centrada na Europa e imposta ao resto do mundo como um desenho global, Dussel propõe que se enfrente a modernidade eurocentrada através de uma multiplicidade de respostas críticas descoloniais que partam das culturas e lugares epistémicos subalter- 
nos de povos colonizados de todo o mundo. $\mathrm{Na}$ interpretação que Walter Mignolo faz de Dussel, a transmodernidade seria equivalente à "diversalidade enquanto projecto universal", que é o resultado do "pen samento crítico de fronteira" enquanto intervenção epistémica dos diversos subalternos (Mignolo, 2000). As epistemologias subalternas poderiam fornecer, segundo a redefinição do conceito do pensador caribenho Edward Glissant por Walter Mignolo (2000), uma "diversalidade" de respostas para os problemas da modernidade, conduzindo à "transmodernidade".

Para Dussel, a filosofia da libertação só pode surgir se os pensadores críticos de cada cultura entrarem em diálogo com outras culturas. Uma das ilações é que as diferentes formas de democracia, os direitos civis e a emancipação das mulheres só podem surgir das respostas criativas de epistemologias locais subalternas. Assim, e por exemplo, as mulheres ocidentais não podem impor a sua noção de emancipação às mulheres islâmicas. Os homen s ocidentais não podem impor a sua noção de democracia a povos não-ocidentais. Isto não é um apelo a uma solução fundamentalista ou nacionalista para a persistência da colonialidade ou para um particularismo de incidên cia local e isolada. É um apelo ao pensamento crítico de fronteira, como estratégia ou mecanismo conducente a um "mundo tran smoderno" descolonizado enquanto projecto universal que nos leve além do eurocentrismo e do fundamentalismo. 
Nos últimos 510 anos do "sistema-mundo patriarcal/capitalista colonial/moderno europeu/euro-americano", passámos do "cristianiza-te ou dou-te um tiro" do século XVI, para o "civiliza-te ou dou-te um tiro" do século XIX, para o "desenvolve-te ou dou-te um tiro" do século XX, para o recente "neoliberaliza-te ou dou-te um tiro" dos finais do século XX e para o "democratiza-te ou dou-te um tiro" do início do século XXI. Não houve respeito nem reconhecimento pelas formas de democracia indígenas, fossem elas africanas, islâmicas, ou outras não-europeias. A forma liberal da democracia é a única aceite e legitimada. As formas outras de democracia são rejeitadas. Se a população não-europeia não aceita as condições da democracia liberal euro-americana, esta é imposta pela força em nome da civilização e do progresso. É preciso reconceptualizar a democracia de maneira transmoderna, de modo a que seja descolonizada da democracia liberal, ou seja, da forma ocidental de democracia, que é uma forma racializada e centrada no capitalismo.

Ao radicalizar a noção levinasiana de exterioridade, Dussel vê uma potencialidade radical nos espaços relativamente externos que não foram totalmente colonizados pela modernidade europeia. Estes espaços externos não são puros nem absolutos. Foram afectados e produzidos pela modernidade europeia, mas nunca totalmente subsumidos ou instrumentalizados. É a partir da geopolítica do conhecimento desta relativa exterioridade, ou margens, que emerge o "pen samento crítico de fronteira" como uma crítica da moder- 
nidade, com vista a um mundo transmoderno pluriversal (Mignolo, 2000) de múltiplos e diversos projectos ético-políticos em que poderia existir um diálogo e uma comunicação verdadeiramente horizontais entre todos os povos do mundo. No entanto, para concretizar este projecto utópico é essencial transformar os sistemas de dominação e de exploração da actual matriz de poder colonial do sistema-mundo patriarcal/capitalista colonial/moderno. Os conflitos anticapitalistas na actualidade A influência nociva da colonialidade, em todas as suas manifestações aos diferentes níveis (global, nacional, local), a ssim como os respectivos saberes eurocêntricos, têm-se reflectido em movimentos anti-sistémicos e pensamento utópico por todo o mundo. Assim, a primeira tarefa de um projecto de esquerda renovado é confrontar-se com as colonialidades eurocêntricas não apenas da direita mas ta mbém da esquerda. Muitos projectos de esquerda, por exemplo, subestimaram as hierarquias étnico-raciais, e quando assumiram o controlo das estruturas estatais acabaram por reproduzir, no seio das suas organizações, o domínio branco/eurocentrado sobre os povos não-europeus. A 'esquerda' internacional nunca problematizou, de forma radical, as hierarquias étnico-raciais construídas durante a expansão colonial europeia e que ainda hoje se encontram presentes na "colonialidade do poder" mundial. Nenhum projecto radical poderá hoje ter êxito sem antes desmantelar estas hierarquias coloniais/raciais. A subestimação do problema 
da colonialidade contribuiu, em grande medida, para a desilusão popular perante os projectos "de esquerda". A democracia (liberal ou radical) não poderá ser concretizada na totalidade enquanto as dinâmicas coloniais/raciais mantiverem grande parte ou, em alguns casos, a maioria da população sob o estatuto de cidadãos de segunda.

A perspectiva aqui enunciada não é uma defesa da "política de identidade". As identidades subalternas poderiam servir de ponto de partida epistémico para uma crítica radical dos paradigmas e modos de pensar eurocêntricos. Porém, uma "política de identidade" não é o mesmo que a alteridade epistemológica. O âmbito da "política de identidade" é limitado, não podendo alcançar uma transformação radical do sistema e da respectiva matriz de poder colonial. Uma vez que todas as identidades modernas são uma construção da colonialidade do poder no mundo colonial/moderno, a sua defesa não é tão subversiva como pode parecer à primeira vista. A identidade "negra", "indiana", "africana" ou identidades nacionais como a "colombiana", "queniana" ou "francesa" são con struções coloniais. A defesa destas identidades poderá eventualmente servir propósitos progressistas, dependendo do que está em causa num determinado contexto. Por exemplo, nas lutas contra uma invasão imperialista ou em confrontos anti-racistas contra a supremacia branca, estas identidades poderão servir para unificar o povo oprimido contra um inimigo comum. Contudo, a política de identidade só serve os objectivos de um único grupo e 
exige a igualdade dentro do sistema, ao invés de desenvolver uma luta anticapitalista radical contra o sistema. O sistema de exploração é um espaço de intervenção crucial que requer alianças mais vastas, em termos não apenas de raça e diferença sexual, mas também de classes e entre uma diversidade de grupos oprimidos, em torno da radicalização da noção de igualdade social. Mas, ao contrário da noção limitada, abstracta e formal de igualdade que é típica da modernidade eurocêntrica, a ideia aqui é alargar a noção de igualdade a todas as relações de opressão, sejam elas raciais, de classe, sexuais ou de género. $\mathrm{O}$ novo universo de significação ou novo imaginário de libertação necessita de uma linguagem comum, apesar da diversidade de culturas e formas de opressão. Esta nova linguagem comum poderia ser obtida através da radicalização das noções libertadoras nascidas do velho padrão de poder colonial/moderno, tais como a liberdade (de imprensa, religiosa ou de expressão), as liberdades individuais ou a igualdade social, ligando-as a uma democratização radical das hierarquias políticas, epistémicas, de género, sexuais, espirituais e económicas do poder à escala global. A proposta que Quijano faz de uma "socialização do poder", por oposição a uma "nacionalização estatista da produção", é fundamental aqui (Quijano, 2000). Em vez de projectos "estatais socialistas" ou "estatais capitalistas" centrados na administração do Estado e nas estruturas hierárquicas do poder, a estratégia da "socialização do poder" em todas as esferas de 
existência social privilegia os conflitos locais e globais a favor de formas colectivas de autoridade pública.

As comunidades, empresas, escolas, hospitais e todas as instituições que actualmente regulam a vida social seriam autogeridas por gente apostada em alargar a igualdade social e a democracia a todos os espaços do existir social. Trata-se de um processo de capacitação e de democratização radical a partir de baixo que não exclui a formação de instituições públicas globais para democratizar e socializar a produção, a riqueza e os recursos a uma escala mundial. A socialização do poder também iria implicar a formação de instituições globais para lá das fronteiras nacionais ou estatais, de modo a garantir a igualdade e justiça na produção, reprodução e distribuição dos recursos mundiais. Isto exigiria algum tipo de organização global democrática autogerida, que funcionasse como uma autoridade colectiva global com o fim de garantir a justiça social e a igualdade social à escala mundial. A socialização do poder ao nível local e global implicaria a criação de uma autoridade pública que fosse exterior e contrária às estruturas estatais.

Baseando-se nas antigas comunidades indígenas dos Andes e nas novas comunidades urbanas marginais, em que a reciprocidade e a solidariedade são as principais formas de interacção social, Quijano vê o potencial utópico de um elemento privado social, alternativo à propriedade privada, e de um elemento público não-estatal igualmente alternativo, para lá das noções capitalistas/socialistas de privado e público. Este elemento público não- 
-estatal (por oposição à identificação do estatal com o público na ideologia liberal e socialista) não está, segundo Quijano, em contradição com um elemento privado de índole social (por oposição a uma propriedade privada de tipo empresarial e capitalista). O privado social e a sua autoridade ins titucional pública não-estatal não contradizem as liberdades pessoais/individuais nem o desenvolvimento colectivo. Um dos problemas do discurso liberal e socialista é que o Estado é sempre a in stituição de autoridade pública em contradição com o desenvolvimento de um crescimento alter nativo do "privado" e dos "indivíduos".

Os projectos desenvolvimentistas que se centram nas mudanças de políticas ao nível do Estado-nação são obsoletos no actual quadro da economia-mundo, conduzindo a miragens de tipo desenvolvimentista. Um sistema de dominação e exploração que opere à escala mundial, como é o caso do sistema-mundo capitalista, não pode ter uma "solução nacional". Um problema global não pode ser resolvido no plano do Estado-nação. São necessárias soluções descoloniais de âmbito global. Assim, a descolonização da economia política do sistema-mundo patriarcal/capitalista colonial/moderno exige a erradicação das contínuas transferências de riqueza do Sul para o Norte e a institucionalização de uma redistribuição global e da transferência de riqueza do Norte para o Sul. Depois de séculos de "acumulação por espoliação" (Harvey, 2003), o Norte detém uma concentração de riqueza e recursos ina- 
cessíveis ao Sul. Poderia promover-se mecanismos globais com vista a redistribuir a riqueza do Norte para o Sul, por meio da intervenção directa de organizações internacionais e/ou pela aplicação de impostos sobre os fluxos globais de capital. Contudo, isto exigiria uma luta de poder descolonial e global, com vista a uma transformação da matriz global e colonial de poder e, por consequência, uma transformação do sistema-mundo patriarcal/capitalista colonial/moderno. O Norte mostra-se relutante em partilhar a concentração e acumulação de riqueza gerada pelo trabalho não-europeu do Sul depois de anos de exploração e dominação. Ainda hoje, as políticas neoliberais representam uma continuação da "acumulação por espoliação" (Harvey, 2003) iniciada pela expansão colonial europeia com a conquista das Américas no século XVI. Muitos países periféricos viram-se privados da sua riqueza e recursos nacionais durante os últimos vinte anos de neoliberalismo à escala mundial, sob a supervisão e intervenção directa do Fundo Monetário Internacional e do Banco Mundial. Estas políticas conduziram à bancarrota muitos países da periferia e levaram à transferência da riqueza do Sul para grandes empresas e instituições financeiras transnacionais sediadas no Norte. O espaço de manobra das regiões periféricas é muito reduzido, devido aos constrangimentos à soberania dos Estados-nação periféricos impostos pelo sistema interestatal global. Resumindo, a solução para as desigualdades sociais exige que se imaginem alternativas descoloniais globais utópicas e que se superem os modos binários de pensamento em termos de colonialistas e nacionalistas, 
fundamentalistas eurocêntricos e fundamentalistas de Terceiro Mundo.

Rumo a um projecto "de diversalidade anticapitalista descolonial, universal e radical"

A necessidade de uma linguagem crítica comum de descolonização requer um tipo de universalidade que já não seja um desenho imperial global/universal monológico e monotópico, quer de direita ou de esquerda, imposto ao resto do mundo pela persuasão ou pela força e em nome do progresso

ou da civilização. A esta nova forma de universalidade, enquanto p rojecto de libertação, chamarei "diversalidade anticapitalista descolonial universal radical". Ao contrário dos universais abstractos das epistemologias eurocêntricas, que subsumem/diluem o particular no que é indiferenciado, uma "diversalidade anticapitalista descolonial universal radical" é um universal concreto que constrói um universal descolonial, respeitando as múltiplas particularidades locais nas lutas contra o patriarcado, o capitalismo, a colonialidade e a modernidade eurocentrada, a partir de uma variedade de projectos históricos ético-epistémicos descoloniais. Isto representa uma fusão entre a "transmodernidade" de Dussel e a "socialização do poder" de Quijano. A transmodernidade de Dussel conduziu-nos ao que Walter Mignolo (2000) caracterizou como "diversalidade enquanto projecto universal" para descolonizar a modernidade eurocentrada, ao passo que a socialização do poder de Quijano faz um apelo a um novo tipo de imaginário universal 
anticapitalista radical que descolonize as perspectivas marxistas/socialistas dos seu s limites eurocêntricos. A linguagem comum deverá ser anticapitalista, antipatriarcal, anti-imperialista e contra a colonialidade do poder, rumo a um mundo em que o poder seja socializado sem deixar de se manter aberto a uma diversalidade de formas institucionais de socialização do poder assentes nas diferentes respostas ético-epistémicas descoloniais dos grupos subalternos do sistema-mundo. Caso não seja redefinido e reconfigurado a partir de uma perspectiva transmoderna, o apelo de Quijano no sentido de uma socialização do poder poderá tornar-se em mais um universal abstracto conducente a um desenho global. As formas de luta anticapitalista e de socialização do poder que emergem no mundo islâmico são bastante diferentes das que emergem nos povos indígenas das Américas ou nos povos bantu da África Ocidental. Todas partilham o projecto anti-imperialista, antipatriarcal, anticapitalista descolonial, mas dão ao projecto da socialização do poder concepções e formas institucionais diversas, de acordo com as suas múltiplas e diferentes epistemologias. Reproduzir os desenhos globais eurocêntricos socialistas do século XX, que partiram de um centro epistémico eurocentrado e unilateral, não faria mais do que repetir os erros que conduziram a esquerda a um desastre global. Do que aqui se trata é de um apelo a um universal que seja um pluriversal (Mignolo, 2000), um apelo a um universal concreto que há-de incluir todas as particularidades epistémicas rumo a uma "socialização transmoderna e descolonial do poder". Como dizem os zapatistas, "luchar por un mundo donde otros mundos sean possibles". 


\section{Referências bibliográficas}

Anzaldúa, Gloria (1987), Borderlands/La Frontera: The New Mestiza. San Francisco:

Spinsters/Aunt Lute.

Castro-Gomez, Santiago (2003), "La Hybris del Punto Cero: Biopolíticas imperiales y

colonialidad del poder en la Nueva Granada (1750-1810)”. Manuscrito inédito.

Bogotá, Colombia: Instituto Pensar, Universidad Javeriana.

Collins, Patricia Hill (1990), Black Feminist Thought: Knowledge, Consciousness and the

Politics of Empowerment. New York: Routledge, Chapman and Hall.

Crenshaw, Kimberle (1989), "Demarginalizing the Intersection of Race and Sex: A Black

Feminist Critique of Antidiscrimination Doctrine, Feminist Theory, and Antiracist

Politics", in Feminism in the Law: Theory, Practice, and Criticism. Chicago: University of Chicago Legal Forum, 139-67.

Dussel, Enrique (1977), Filosofía de Liberación. México: Edicol.

Dussel, Enrique (1994), 1492: El encubrimiento del Otro: Hacia el origen del "mito de la

modernidad". La Paz, Bolivia: Plural Editores.

Dussel, Enrique (2001), Hacia una Filosofía Política Crítica. Bilbao, España: Desclée de

Brouwer. 
Enloe, Cythia (1990), Banana, Beaches and Bases: Making Sense of International Politics.

Berkeley: University of California Press.

Fanon, Frantz (1967), Black Skin, White Masks. Grove Press: New York.

Frank, Andre Gunder (1969), Capitalism and Underdevelopment in Latin America. New

York: Monthly Review Press.

Fregoso, Rosa Linda (2003), MeXicana Encounters: The Making of Social Identities in

the Borderlands. Berkeley: University of California Press.

Grosfoguel, Ramón (1996), "From Cepalismo to Neoliberalism: A World-System

Approach to Conceptual Shifts in Latin America”, Review, 19(2), 131-154.

Grosfoguel, Ramón (2002), “Colonial Difference, Geopolitics of Knowledge and Global

Coloniality in the Modern/Colonial Capitalist World-System”, Review, 25(3), 203-224.

Grosfoguel, Ramón (2005), “The Implications of Subaltern Epistemologies for Global

Capitalism: Transmodernity, Border Thinking and Global Coloniality", in William

Robinson; Richard Applebaum (orgs.), Critical Globalization Studies. London: Routledge.

Grosfoguel, Ramón (2006a), "From Postcolonial Studies to Decolonial Studies: Decolo-

nizing Postcolonial Studies: A Preface”, Review, 29(2). 
Grosfoguel, Ramón (2006b), "World-System Analysis in the Context of Transmodernity,

Border Thinking and Global Coloniality", Review, 29(2).

Haraway, Donna (1988), "Situated Knowledges: The Science Question in Feminism

and the Privilege of Partial Perspective", Feminist Studies, 14, 575-99.

Harvey, David (2003), The New Imperialism. Oxford and New York: Oxford University

Press.

Kontopoulos, Kyriakos (1993), The Logic of Social Structures. Cambridge: Cambridge

University Press.

Lander, Edgardo (1998), "Eurocentrismo y colonialismo en el pensamiento social lati-

noamericano", in Roberto Briceño-León; Heinz R. Sonntag (orgs.), Pueblo, época $\mathrm{y}$

desarrollo: la sociología de América Latina. Caracas: Nueva Sociedad, 87-96.

Mallon, Florencia (1994), “The Promise and Dilemma of Subaltern Studies: Perspectives

from Latin American History", American Historical Review, 99, 1491-1515.

Mignolo, Walter (1995), The Darker Side of the Renaissance: Literacy, Territoriality and

Colonization. Ann Arbor: The University of Michigan Press.

Mignolo, Walter (2000), Local Histories/Global Designs: Essays on the Coloniality of 
Power, Subaltern Knowledges and Border Thinking. Princeton: Princeton University

Press.

Moraga, Cherrie; Anzaldúa, Gloria (orgs.) (1983), This Bridge Called my Back: Writing

by Radical Women of Color. New York: Kitchen Table/Women of Color.

Quijano, Aníbal (1991), “Colonialidad y Modernidad/Racionalidad”, Perú Indígena, 29,

11-21.

Quijano, Aníbal (1993), “'Raza', 'Etnia’ y 'Nación’ en Mariátegui: Cuestiones Abiertas", in Roland Morgues (org.), José Carlos Mariátgui y Europa: El Otro Aspecto del Descubrimiento. Lima, Perú: Empresa Editora Amauta S.A., 167-187.

Quijano, Aníbal (1998), "La colonialidad del poder y la experiencia cultural latinoa-

mericana”, in Roberto Briceño-León; Heinz R. Sonntag (orgs.), Pueblo, época y desarrollo: la sociología de América Latina. Caracas: Nueva Sociedad, 139-155.

Quijano, Aníbal (2000), "Coloniality of Power, Ethnocentrism, and Latin America”,

NEPANTLA, 1(3), 533-580.

Rodriguez, Ileana (2001), "Reading Subalterns Across Texts, Disciplines, and Theories:

From Representation to Recognition", in Ileana Rodriguez (org.), The Latin American

Subaltern Studies Reader. Duke University Press: Durham and London. 
Said, Edward (1979), Orientalism. New York: Vintage Books.

Saldívar, José David (1997), Border Matters. Berkeley: University of California Press.

Spivak, Gayatri (1988), In Other Worlds: Essays in Cultural Politics. New York: Routledge,

Kegan and Paul.

Wallerstein, Immanuel (1974), The Modern World-System. New York: Academic Press.

Wallerstein, Immanuel (1979), The Capitalist World-Economy. Cambridge and Paris:

Cambridge University Press and Editions de la Maison des Sciences de l'Homme.

Wallerstein, Immanuel (1983), Historical Capitalism. New York: Monthly Review Press.

Wallerstein, Immanuel (1984), The Politics of the World-Economy. Cambridge/ Paris:

Cambridge University Press/ Editions de la Maison des Sciences de l’Homme.

Wallerstein, Immanuel (1991a),Unthinking Social Science. Cambridge: Polity Press.

Transmodernidade, pensamento de fronteira e colonialidade global | 147

Wallerstein, Immanuel (1991b), Geopolitics and Geoculture. Cambridge/ Paris: $\mathrm{Cam}^{-}$

bridge University Press/ Editions de la Maison des Sciences de l'Homme. 
Wallerstein, Immanuel (1992a), "The Concept of National Development, 19171989:

Elegy and Requiem", American Behavioral Scientist, 35(4/5), March-June, 517529.

Wallerstein, Immanuel (1992b), "The Collapse of Liberalism”, in Ralph Miliband; Leo

Panitch, The Socialist Register 1991. London: The Merlin Press, 96-110.

Wallerstein, Immanuel (1995), After Liberalism. New York: The New Press. 